\title{
UMA IMAGEM DA CULTURA EM MICHEL FOUCAULT E E. P. THOMPSON
}

\section{Prof. ${ }^{a}$ Dr. ${ }^{a}$ Margareth Rago (UNICAMP)}

Devo dizer que, no início, me surpreendi com a proposta e me perguntei: por que falar de Foucault e Thompson ainda hoje? Eu tinha absoluta certeza de que iria falar para historiadores. Tinha certeza de que Osmar era um historiador e de que estava no Departamento de História de Alagoinhas. Mas quando li os resumos do que seria apresentado na oficina que faríamos pela manhã, e enquanto os lia, me surpreendi ainda mais. Afinal, refletia, como os historiadores de Alagoinhas haviam mudado! A UNICAMP estaria tão atrás e eles tão à frente, porque os resumos eram totalmente interdisciplinares?

Quando soube que se tratava de um pessoal da Literatura e Crítica Cultural, me senti reconfortada, pois considero que essas novas áreas realmente têm reflexões específicas, debatem determinadas questões que, em geral, não atraem grande parte dos historiadores. Contudo, continuei com a dúvida, dessa vez ainda maior: por que então falar para esse grupo, sobre Thompson e Foucault, sobre um debate já antigo e que tem a ver mais com a História e com a minha história pessoal?

Passei por essa discussão que envolvia os dois autores citados, quando fiz mestrado, no início da década de 80, e um pouco no doutorado, que concluí em 1990. Hoje já não é mais um debate, as questões se aclararam mais, as fronteiras se definiram. Hoje creio que até virou brincadeira, ou já nem nos lembramos mais dessa história. Rimos um pouco disso, porque percebemos que era uma besteira ficar disputando autores como Foucault, um filósofo, e Thompson, um historiador. Teria sido muito mais inteligente descobrir como conectá-los e não estabelecer uma competição entre ambos. Mas eram outros tempos.

De certa maneira, ao falar de ambos, é inevitável retomar a minha própria experiência pessoal e intelectual, porque vivi um debate que se caracterizou como uma grande disputa entre grupos que se alinhavam na história social e na história cultural, e eles eram dois fortes expoentes: Thompson na história social, e Foucault, segundo uma apropriação dos historiadores, na história cultural. É inevitável falar dessa minha 
experiência, que também tem a ver com o contexto político do Brasil, já que envolve a abertura política do país, como foi ressaltado aqui anteriormente, em especial no que tange ao debate do marxismo e do pós-estruturalismo.

É nesse campo que vou fazer minhas colocações, situando-me também enquanto portadora de uma experiência pessoal e intelectual. Mas queria dizer-lhes também, antes de entrar no assunto propriamente dito, que, tendo ouvido a mesa apresentada anteriormente, fui instigada a pensar no sentido desse evento que nos reúne. Não sei se captei bem, mas queria manifestar-lhes a minha sensação, o fato de ter ficado muito contente ao me dar conta do presente que recebo ao poder compartilhar esse momento da experiência de vocês, porque tenho a sensação muito forte de que estou vivendo um momento de grande virada aqui, já que as falas que me antecederam enfatizaram a questão da origem, da origem histórica, a narrativa da fundação. Da fala sobre a antropofagia, passando pela fala da professora e do artista, nós falamos dos mitos da fundação, o que tem tudo a ver com Foucault e Thompson.

É inevitável, então, a pergunta: quando é que fazemos balanços? Quando buscamos entender o passado? Quando fazemos trabalhos como os da biografia, ou autobiografia? Em geral, entendo que recorremos ao passado especialmente quando uma grande mudança está em vias de ocorrer. Quando uma ruptura se insinua e é assim que eu estou sentindo este preciso momento. Tenho a sensação de que um ciclo se encerra e que vocês entram em um novo patamar. Então, quero agradecer por estar participando desse rito de passagem. Acabo vendo esse momento como um rito de passagem e eu não tinha essa noção antes de chegar a esta universidade. Desde São Paulo, não estava entendendo bem de que tipo de evento se tratava e o tempo todo estive buscando entender por que fui chamada para falar de Thompson e Foucault aqui, num lugar que não é só de historiadores, e por que neste exato momento. Quero dizer, portanto, que parabenizo a todos e todas por terem chegado a esse ponto e acho importante que vocês tenham claro que ponto é esse onde estão se situando agora. Estou aqui parafraseando o nome do livro do meu amigo, o historiador Paulo Miceli, intitulado $O$ ponto em que estamos. O ponto em que vocês estão, ou o ponto em que estamos, afinal o país é um só, ao menos por enquanto, não sei o que vai acontecer daqui a pouco. 
Mas, agora, vou entrar no tema "imagens culturais em Foucault e Thompson".

Em 1980, quando comecei o mestrado no Programa de Pós-Graduação em História da UNICAMP - sou historiadora de formação - , tinha feito a USP no final dos anos 60 (entre 1967 e 1970). Nessa geração, todo mundo entrava no curso de História pensando em fazer a revolução. Em História, em Sociologia, em outros cursos também. E como todo mundo, me atirei na piscina vazia, caí no buraco como todo mundo e sofri igualmente. Foi aquela sensação de vazio, quando encerramos o curso. Das tentativas de militância política, o gosto amargo das desventuras, das prisões, das notícias de desaparecimento, da sensação de derrota. Até que parei, voltei para casa e decidi ficar quieta. Passaram-se alguns anos e eu não tinha ainda achado o momento de voltar para o curso de História e não queria fazer o mestrado assim sem ter convicção de minha escolha. Queria fazer a revolução e estava muito triste porque não tinha conseguido fazê-la.

Então, fui cursar Filosofia na USP, entre 1976 e 1979/80, em busca de novos rumos. Lá encontrei Foucault, entre outros autores. Em 1977/78, vários daqueles professores em Filosofia estavam introduzindo Foucault, Deleuze, Nietzsche, e eu não entendia nada, mas não tinha importância porque também não tinha entendido nada antes e continuo não entendendo. Marx é dificílimo. Quem consegue entender tão bem O Capital? Cada um entende uma coisa e é aquela briga toda para se definir quem é mais marxista do que o outro. Então, em 1980, decidi que tinha de voltar para a História, e fazer pós-graduação. Assim, fiz tudo na década de 1980: mestrado, doutorado, casamento, tive uma filha...

Nesse momento na Unicamp, falava-se de muitos autores, de muitas descobertas, não só do E. P. Thompson, mas também de Claude Leffort, Walter Benjamin, Cornelius Castoriadis, Hannah Arendt, aquele leque de autores que nos deixavam maravilhados de perceber tantas reflexões, tantas coisas, e era aquela descoberta enorme. As conhecidas filósofas Marilena Chauí e Maria Silvia de Carvalho Franco chegaram a realizar cursos incríveis em nosso Programa de Pós-Graduação em História. Aos poucos, para um grupo, o debate se polarizou entre Thompson e Foucault, entre História Social e o que aos poucos se configurava como História Cultural, entre os historiadores, entre uma aposta na concepção de que as relações sociais de produção explicam outras dimensões 
da vida, constituindo-se como lugar privilegiado de inteligibilidade do real, e outra, muito diferente, segundo a qual a sociedade e o real são conceitos que devem ser desnaturalizados e historicizados. Mas quero destacar que o leque de autores/as que líamos era muito maior, e é ainda. Hoje, ainda mais, porque há muito mais gente, e muitas autoras também.

De certa maneira, vou abordar os dois autores mais teoricamente, mas naquele momento eram vários autores que nos fascinavam, momento em que os movimentos sociais estavam acontecendo no país com novo vigor. Era um momento de muita ebulição, a fundação e crises do PT, os anarquistas, as feministas, o movimento negro, o movimento homossexual... Era, sem dúvida, uma pluralidade de autores e de acontecimentos que nos fascinavam e seduziam. Eu trazia na minha mochila, quando cheguei na UNICAMP, o Foucault, porque vinha do curso de Filosofia da USP, mas ainda não tinha uma paixão consolidada por ele, digamos assim. Gostava muito das suas ideias, mas não sabia ainda que gostava tanto. Depois, quando as pessoas me diziam que eu só falava do Foucault, é que eu fui pensar no assunto. Eu acreditava que gostava de outros autores também, tanto que fiz esse trabalho de mestrado publicado em livro como Do cabaré ao lar: a utopia da cidade disciplinar, Brasil, 1890-1930, Editora Paz e Terra, em que fazia um estudo sobre a formação do proletariado no Brasil, mostrando como os anarquistas foram críticos daquela modernidade que estava se instaurando com a imigração e com os europeus que aqui chegavam.

No mesmo momento em que nascia a família nuclear, um modelo de família específico da modernidade, do mundo industrial, com todas as suas implicações, os anarquistas criticavam, afirmando que o amor não pode ser eterno, contestando o casamento monogâmico indissolúvel. O amor, diziam eles, tem de ser livre, as pessoas devem decidir com quem e como querem viver e não ter de prestar contas para o Estado e para a Igreja. Meu trabalho, portanto, foi essa busca de tentar entender esse movimento da constituição da classe operária, para o que Thompson era muito útil teoricamente, mas Foucault também.

A grande crítica que recebi quando terminei a dissertação foi que queria casar dois autores que não poderiam ser casados, pois eram totalmente diferentes. A princípio, fiquei muito chateada, porque eu não acreditava que deveria escolher entre um ou outro, 
já que gostava dos dois e as pessoas viviam naquela coisa de ser ou thompsoniano ou foucaultiano. Se você é marxista, você não pode ser pós-estruturalista; se você é pósestruturalista, não pode ser marxista. Foi um impasse para mim, porque os dois eram muito úteis e queridos, traziam conceitos interessantíssimos, abriam novas perspectivas para pensar a formação da classe operária e outras questões mais amplas. Além do mais, eu raciocinava, se a grande Michelle Perrot, ou se Alain Corbin se valem desses dois autores, por que não posso fazer o mesmo? Mas não era suficiente dizer isso, e creio que essa crítica teve um efeito muito positivo, porque me levou a estudar muito mais o campo teórico em que se inscreviam esses pensadores, especialmente Foucault, muito mais difícil, pois filósofo intenso.

Foi bom, as críticas são boas, porque como eu queria me defender bem, passei muitos anos tentando entender tudo isso, até que os novos temas da pesquisa de doutorado me levaram a enveredar muito mais pelo pensamento de Foucault, o que se desdobrou no contato com o Gilles Deleuze e com outros autores. De certa maneira, fui deixando Thompson de lado por conta de abandonar também o estudo de classe operária, porque quando fazia essa pesquisa de mestrado sobre o proletariado, fui descobrindo que a classe operária era composta em grande parte por mulheres e que precisava de outras referências teóricas para ampliar a pesquisa, inclusive para o campo da sexualidade.

Quando se estudam a revolução industrial e a história do proletário no Brasil, descobre-se que metade do operariado era constituído por mulheres jovens, de quinze, dezesseis anos e por crianças. Então, fiquei inconformada porque a historiografia não falava disso, havia sempre "o proletariado" nas páginas dos livros e com isso pensavase apenas nos homens. Para mim, não é a mesma coisa ser homem ou mulher, em qualquer coisa que a gente faça na vida, a questão de gênero é fundamental. Fui dando uma atenção especial à questão das mulheres e, obviamente, se você estuda as mulheres, passa inevitavelmente pela história da família e da sexualidade. O tema passa por aí. E fui me dando conta de que não sabia de nada. De que não havia história das mulheres no Brasil, nem história da família, à exceção de alguns trabalhos recentes, nem história da sexualidade, da maternidade, do aborto, da prostituição, enquanto que na Europa isso já estava sendo produzido, assim como nos EUA. Enfim, todo esse movimento foi-me afastando do Thompson, porque fui abandonando a história da classe operária, abrindo- 
me para outras temáticas e discussões. Thompson é um autor marxista heterodoxo, é um pensador que ampliou muito o marxismo, que o renovou; considero-o brilhante e maravilhoso. Aprendi muito com ele e ainda tenho muito a aprender, mas para dar conta das temáticas com as quais eu passava a lidar, era necessário buscar outros conceitos, outros modos de pensar, outras referências teóricas e metodológicas.

Meu doutorado resultou num livro intitulado Os Prazeres da Noite, Prostituição e Códigos da Sexualidade Feminina em São Paulo (Editora Paz e Terra, 1991), republicado em 2008. Para escrever sobre a história da prostituição e da sexualidade, é Foucault quem abre as portas. Então, pensei numa imagem que me facilita dizer para vocês porque me aproximei cada vez mais de Foucault, porque meu investimento intelectual a partir de então se voltou muito mais para esse autor.

Essa imagem é a seguinte. Há pouco tempo alguém me passou um livro de um autor japonês já falecido, chamado Junichiro Tanizaki, que se chama Em louvor da sombra. No livro, o autor explica a importância da sombra na cultura oriental. Segundo ele, os japoneses mais antigos não gostavam muito da claridade; por exemplo, eles preferiam um quarto em penumbra a um quarto claro, porque a penumbra é mais aconchegante, mais arredondada, mais acolhedora do que o branco hospitalar. Ele diz que os japoneses não costumam arear panelas, não apreciam panelas brilhantes, nem mesmo querem usar panelas de metal, preferindo as de cobre, porque são melhores para cozinhar os alimentos. Não passaria pela cabeça das pessoas, no Japão antigo, que dentes amarelados possam ser considerados feios. O autor mostra uma série de situações e lugares em que a sombra é muito mais importante do que a luz.

Trouxe-lhes o conteúdo desse livro, porque me dei conta, ao lê-lo, de que nunca tinha pensado na sombra e, com isso, quero dizer que Foucault me leva a este movimento: é alguém que me faz ver coisas que nunca tinha visto ou pensado. Enquanto historiadora, ele me faz pensar em dimensões, processos, acontecimentos, que nunca havia imaginado, já que ele tem como questão maior a produção de um pensamento diferente, de um pensamento capaz de enxergar o outro em sua positividade, e não subsumido à nossa própria lógica. Adoro essa aventura do pensamento a que Foucault nos convida. Creio que a sua questão não é propriamente a de entender o passado, explicar a história como é para um historiador; considero que ele 
não é um historiador, mas um filósofo, e como tal, a sua questão é entender por que pensamos assim e não de outra maneira e criar novos modos de pensar, novos conceitos, novos olhares. Está em questão a nossa racionalidade, a maneira como operamos. É claro que, ao mesmo tempo, eu o considero um exímio historiador, porque as pesquisas que realizou e os livros de história que escreveu, como Vigiar e Punir, a História da Sexualidade, A História da Loucura, são absolutamente inéditos, originais e brilhantes.

As questões que Foucault lança são surpreendentes e instigantes. Levam a pensar, por exemplo, por que há trinta anos, a homossexualidade era considerada um comportamento patológico e hoje está sendo despatologizada? O que aconteceu? Quem é o responsável por isso? Uma série de questões que a gente não se colocava de repente emergem como problemas. Por quê? Por que o mundo deu uma guinada de 180 graus nas últimas décadas? Quem é da minha geração sabe que o mundo deu essa guinada, desde as décadas de sessenta e setenta aos nossos dias, de uma maneira muito ampla. Como já foi dito aqui durante os comentários, colocou-se fortemente essa questão de que não dá para se restringir a uma única referência, mesmo quando falamos em arte, ou quando falamos em poder, mas temos de pensar a vida em todas as suas dimensões e em sua multiplicidade. Por exemplo, hoje não é mais possível aceitar a figura de um revolucionário, homem ou mulher, que seja machista, ou racista. Um revolucionário racista, em nossos tempos, é um absurdo. As nossas exigências aumentaram muito. $\mathrm{O}$ nosso mundo é mais sofisticado, é muito mais complexo e nós aprendemos muito. É verdade que a ditadura nos abafou, mas as lutas de resistência nos tornaram pessoas muito mais atentas, espertas, ligadas e politizadas. Porque houve um crescimento mental, intelectual ou espiritual, não sei como se chama.

Então, voltando aos dois autores, a primeira diferença que gostaria de destacar é essa: um historiador está interessado em descrever o passado, dar um sentido ou entender o sentido que as pessoas que viveram aquela época, aquela experiência conferiram às suas ações. Enfim, visa fazer uma interpretação de um determinado momento ou contexto histórico, do modo como as pessoas viviam ou sentiam. Para um filósofo não é essa a questão, como não é para Foucault. A sua questão filosófica é: como podemos pensar de outro modo do que pensamos, ver de outro modo do que vemos? Como é possível criar novos mundos, inventar novas subjetividades, ser outros e outras do que somos? E para isso, para responder às suas indagações, Foucault 
recorre à história do Ocidente, recuando progressivamente até chegar nos antigos gregos. Suas últimas aulas, lançadas em 2009, na França, com o título de Le Courage de la Vérité. Le Gouvernement de Soi et des Autres, falam dos estóicos e dos cínicos, de Diógenes e de Epicteto.

Portanto, para poder formular os seus conceitos, Foucault recorre à História. Vou dar um exemplo. Foucault pergunta: por que todo historiador ao estudar o período do final do século XVIII, a virada do século XVIII, na Europa, se centra na Revolução Francesa? Por que todo francês - e ele é francês - vai para o fim do século XVIII estudar esse acontecimento, entendido como o momento da invenção da liberdade, invenção dos direitos humanos (todos nascemos iguais), a invenção da noção de povo, tudo isso que sabemos, mas não citam a invenção da prisão? Ele indaga por que não se fala, então, do nascimento da prisão, algo que acontece no mesmo momento, com as mesmas pessoas, com os mesmos envolvidos. Quer dizer, no mesmo momento em que se tem o nascimento da liberdade, a Revolução Francesa, a noção dos direitos humanos, nasce também a prisão, e mais, mostra ele, constitui-se progressivamente a sociedade panótica, disciplinar, isto é, aquela em que outra modalidade de poder se difunde de forma mais sofisticada, molecular, invisível.

No mesmo momento em que se está falando do contrato social, na fundação do contrato social, com diz Jean-Jacques Rousseau, assiste-se, mostra Foucault, à emergência de um outro tipo de poder que se generaliza por toda a sociedade, e que é um poder imperceptível, molecular, um poder que não está lá no alto, centrado no Estado, no exército, na cúpula, reprimindo, mas que está aqui, no cotidiano da vida social, produzindo as individualidades, separando e capturando os corpos, hierarquizando, segregando, classificando as condutas, produzindo os gestos. $\mathrm{O}$ biopoder em ação, ao contrário da noção de dominação ideológica, que não chega ao corpo.

Para nós mulheres, isso é muito fácil de entender. Vou explicar pelo lado das mulheres, porque sou mulher. No final do século XVIII, há uma grande mudança na medicina: nasce a ginecologia moderna, em meio à Revolução industrial, à Revolução francesa, ao crescimento urbano-industrial e à entrada feminina no espaço público. Nesse momento em que se inaugura a Modernidade, nasce também a ginecologia. E 
esta, como ciência médica, diz que o corpo da mulher é muito diferente do corpo do homem e que os médicos dos séculos anteriores estavam totalmente errados, ao considerarem que mulher e homem eram idênticos. Os médicos achavam que a mulher era um "homem menos", então nem precisava pesquisar um esqueleto feminino, já que pelo esqueleto masculino se entenderia também o corpo feminino, já que a mulher era um "homem menos". Nem se tinha uma linguagem específica, um vocabulário especial para definir os órgãos sexuais femininos, porque a mulher era um "homem menos", como nos mostra o historiador Thomas Laqueur, num belíssimo livro intitulado Inventando o Sexo, dos gregos a Freud. Nesta concepção, a mulher teria pênis, sêmen, orgasmo, participaria da fecundação tanto quanto o homem. Há toda essa concepção do corpo antes do século XIX.

Contudo, se o corpo não muda, as interpretações mudam e muito. Então, nesse momento de nascimento da sociedade moderna, da noção de liberdade, dos direitos iguais para todos, mas também do surgimento da prisão e da expansão do poder molecular, a medicina passa a dizer o seguinte: todos são iguais perante a lei, porém alguns têm um cérebro menos desenvolvido do que outros, por exemplo, as mulheres, ou os negros, ou os indígenas, logo, devem ser comandados pelos mais racionais. Nessa leitura, as mulheres não têm capacidade para votar, menos ainda para dirigir, porque elas têm a grande missão de parir, de serem mães e, com isso, precisam de um tipo de corpo diferenciado do dos homens, necessitam de uma certa energia para poder formar o feto, o que lhes custa o preço de ter menos neurônios do que os homens. Então, há toda uma teoria científica que procura provar essas teses cientificamente, com discursos pretensamente objetivos, mas totalmente moralistas, que concluem que as mulheres, portanto, não poderiam frequentar as universidades, nem exercer determinados cargos públicos. Elas só poderiam estudar assuntos leves, já que são muito influenciáveis. Segundo os doutores, mulheres são mais úmidas que os homens, seus ossos são mais frágeis e, por isso, necessitam descansar, repousar num período do dia. A medicina moderna afirma que a mulher tem líquidos, tem menstruação, o osso é mais fraco, então precisam ter mais cuidados, precisam ser poupadas do mundo público. Obviamente ninguém estava pensando na operária ou camponesa, ninguém estava se referindo às mulheres pobres. Referem-se às mulheres da elite, mas mesmo assim estavam dizendo que essas não poderiam frequentar as universidades e nem participar do poder. Olympe 
de Gouges fez uma crítica feminista violenta sobre a construção excludente da esfera pública, nesse período, e o grande presente que recebeu foi o de ser guilhotinada. Aposto que pouco de vocês ouviram falar do seu nome, já que só ouvimos falar dos homens maravilhosos, da direita ou da esquerda, não tem importância.

Com isso quero mostrar-lhes uma questão colocada por Foucault: a de que enxergávamos apenas um dos lados da moeda, e todo o resto permanecia na sombra. Falávamos do capital, do capitalismo, dos operários, mas deixávamos de lado os que haviam sido excluídos das fábricas, os loucos, delinquentes, criminosos, as mulheres, as crianças, enfim, deixávamos de lado a alteridade. O livro "Vigiar e Punir", portanto, provocou um enorme celeuma, e se foi bem vindo por muitos, também foi muito criticado pelos que achavam que os historiadores não deveriam perder tempo com aqueles que, no marxismo, eram denominados de "lumpemproletariado".

Foucault nos trouxe uma nova noção do discurso, não mais como reflexo superestrutural de uma suposta realidade, mas como prática instituinte, como materialidade, como aquilo que cria os objetos de que fala, como explica Paul Veyne, em seu famoso livro Como se escreve a História. Foucault revoluciona a História. Assim, para ele, o discurso não descreve apenas a coisa de que fala, a realidade a que se refere, mas institui essa própria realidade. Isso fica claro quando pensamos em determinados comportamentos sociais. A loucura, por exemplo. Segundo Foucault, a loucura não descreve práticas sociais essencialmente irracionais, que existiam antes do discurso psiquiátrico, mas resulta da captura de determinados comportamentos pelo discurso médico psiquiátrico, que, com suas regras de formação, criaram um objeto chamado loucura. A partir deste, determinados comportamentos foram alocados como tal, enquanto outros foram vistos como normais, e os sujeitos dessas ações foram considerados loucos ou normais, segundo ainda suas características físicas, corporais, anatômicas e internados em hospícios, asilos, etc.

Assim, é claro que para ele há comportamentos considerados mais ou menos adequados, digamos assim, mas não necessariamente patológicos, irracionais e, não necessariamente, o lugar do louco, para cura, é o hospício. Isso é uma invenção da Modernidade. E é uma invenção da psiquiatria que afirma que aquele comportamento 
da antiga figura do bobo da corte é loucura e que ele tem de ser retirado da sociedade, isto é, internado em alguma instituição psiquiátrica. Isso está explicado em seu livro a História da Loucura, que causou um profundo impacto, quando foi publicado, já que não se tinha pensado que isso seria um tema possível. Aliás, o próprio Foucault teve muita dificuldade em publicar seu livro, porque a Academia francesa dizia que a razão tem história, mas a loucura não. A loucura é a natureza, a natureza não tem história. Tudo que é natural não tem história, porque sempre foi e sempre será.

Não passa muito tempo, Foucault apresenta outro livro, a História da Sexualidade, em 1976. E, na sua História da Sexualidade, ele não está fazendo uma história da vida sexual das pessoas, não é disso que trata. Ele não está fazendo uma história do cotidiano, conferindo como foi a evolução de tal ou qual comportamento sexual, vendo o que era o amor entre os gregos ou entre os romanos, não é disso que se trata. É um livro teórico: o primeiro volume se chama $A$ vontade de saber, em que ele pergunta por que o sexo se tornou tão importante na modernidade. Por que na Grécia é tão importante a alimentação quanto a experiência sexual e, para nós, o sexo se torna rei, ganha centralidade diante de outras dimensões da vida? $\mathrm{Na}$ Antiguidade, os tratados médicos e filosóficos falam tanto da importância da alimentação para o indivíduo, para a formação do jovem, quanto da vida sexual, da experiência sexual. E Foucault se pergunta: por que em nosso mundo a sexualidade adquiriu uma força tão grande, tornou-se tão importante que para qualquer coisa que você faz, você parte do sexo como fundamento? E por que a sexualidade seria universalmente definidora da identidade?

Hoje, em 2009, estamos em um período que já passou por todas essas críticas, mas o livro é do início dos anos 80, quando ninguém falava no assunto e nem pensava que sexualidade tivesse história. E a questão dele era: por que a modernidade faz, então, da sexualidade o rei a partir do qual tudo deriva? Por que se classifica uma pessoa como homossexual? E, aliás, de quando é essa palavra homossexual e de quando é essa partilha entre homossexualidade e heterossexualidade? Foucault mostra que provém da medicina vitoriana, por volta de 1850-1860, quando os médicos começam a dizer que a prática do amor entre dois homens é homossexualidade e que isso é patológico, é doença. Então, ele faz uma história que é muito mais do que a das práticas cotidianas; trata-se, antes, da relação que estabelecemos com determinados domínios da nossa vida, e com a questão moral. 
E por que precisamos hierarquizar o pensamento? Por que pensamos que a economia é determinante e a arte não? Por que se considera que a arte é supérflua e, logo, que o artista é desnecessário, como quer Platão? Qual a implicação política disso? A implicação é que se você for nas universidades, por exemplo, o prédio que abriga a Faculdade de Economia é riquíssimo, maravilhoso, enquanto o Instituto de Artes é minúsculo e nunca tem verba para pesquisas. É óbvio, se no nosso modo de pensar, economia é importante e arte não, o economista é o homem de peso e o artista é supérfluo, tudo isso se torna óbvio. Então Foucault incita a perguntar: Por quê? Quem disse? De onde vem isso? Qual é a tradição de pensamento que cria essas hierarquias, que são excludentes? São excludentes porque uns ficam dentro e outros ficam de fora. Se você repartir a humanidade em homossexuais e heterossexuais, você faz um corte que não é de classe, porque tanto faz se é rico, pobre, branco, negro, brasileiro ou nãobrasileiro. Você cria uma classificação em que metade da população é considerada homossexual, está fora, porque, no discurso médico do passado, a homossexualidade é patológica e a medicina do século XIX teria provado isso. Aliás, esse discurso científico sexista e racista também fundamentou o Código Penal, por exemplo, o brasileiro, que é de 1940. Tudo bem que os/as advogados/as estão fazendo muitas revisões, pensando, é claro, que o mesmo movimento que temos aqui, se tem na área do Direito, na Arquitetura, aqui e ali, mas na prática o que nós temos aqui é isso.

Então, Thompson e Foucault têm diferenças enormes não só pelos objetos de que tratam, mas também pelo tipo de preocupação, pelo método, pelas concepções, pelas interpretações que constroem. Um é historiador, inglês, vindo de uma sociedade marcada pelo empiricismo; o outro é francês, nascido em um universo marcado pelo nominalismo. Isso também aparece em suas produções. Isso aparece na própria maneira de pensar. Ambos são pensadores profundamente inquietos e irreverentes, Thompson, sem dúvida, é um marxista com uma larga experiência fora da academia, que dava cursos em sindicatos, cursos noturnos para operários. Um de seus livros estourou no Brasil na década de 80, mas é de 1963, e lá na UNICAMP, quando o prof. Edgar de Decca, responsável pela tradução dos três volumes publicados pela Editora Paz e Terra, convidou-o para o lançamento, porque ele era um grande sucesso no Brasil, ele respondeu negativamente, afirmando que estava voltado para a questão ambiental, 
ecológica, e que não estava mais interessado naqueles temas. Vinte anos depois, ele estava militando na questão ambiental.

Contudo, há alguns pontos em comum entre esses dois homens admiráveis, muito fascinantes, além do brilho e da inteligência. São pensadores que estão fazendo a crítica da modernidade, a crítica do nosso mundo, a crítica do nosso presente e pensando nas saídas possíveis. Só que cada um a seu modo. Um pelo marxismo e o outro pelo pós-estruturalismo, muito embora Foucault não se preocupasse com autodefinições, ao contrário, sempre queria livrar-se delas. Afinal, ele dedicou a sua vida para construir um pensamento diferente, que tematizasse a diferença de outro modo, e a construir outras formas de reflexão que não fossem as instituídas, que escapassem da lógica da identidade. É conhecida a sua frase: é preciso "sacudir as evidências", estranhar o que é familiar. A prisão é necessária? A fábrica é necessária? Não tem outro modo de crescimento econômico que não seja a fábrica centralizada com opressão dos trabalhadores? Tudo isso é necessário? Não tem mais nada para inventarmos no mundo?

Creio que alguém que faz essas colocações, que coloca tudo sob suspeita, num primeiro momento, irrita profundamente. Fiquei muito surpresa ao constatar como as pessoas se irritavam com Foucault, mas também entendo que elas se irritavam porque ele desestabiliza verdades há muito tempo assentadas e hoje penso que é um grande benefício que alguém faz, quando nos coloca uma dúvida e pergunta: mas precisa ser assim? A única forma de formar um jovem é ensiná-los a ser obedientes e repetitivos? Os gregos faziam assim? Ser obediente, ser cumpridor dos seus deveres, ser isso e aquilo? O que é isso? Cumpridor do dever que quem? Para quem? Isso é cidadania?

Quando Foucault estuda a experiência dos antigos gregos, no volume 2 da História da sexualidade: O uso dos Prazeres, ele diz o seguinte: os gregos estavam preocupados em formar o indivíduo belo, estavam preocupados em construir a vida bela enquanto a modernidade é normatizadora, a modernidade normatizou tudo. A ciência, bebendo no discurso religioso, classificou tudo em termos rígidos, definitivos e estigmatizadores. Todos os gestos, todas as práticas, de sexuais a não-sexuais, tudo em nosso mundo tem nome: pedofilia, onanismo, sadismo, masoquismo, perversão sexual... Há classificações para tudo. E ele pergunta: por que essa obsessão normatizadora? Por que essa idéia de o lugar da criança é a escola, o do louco é o hospício, o do "homem 
normal" é a fábrica, o escritório e o da mulher é o lar? Hoje sabemos que o século XIX construiu a "ideologia da domesticidade", afirmando que lugar de mulher é no privado, na esfera doméstica, cuidando dos filhos. Os séculos XVII e XVIII, por exemplo, atribuem outros espaços às mulheres. A mulher da corte não é destinada ao lar; mostra Norbert Elias que, assim como "as preciosas" da peça de Molière, elas organizavam salões literários, tinham vida própria, diferente da dos seus esposos. Eram mulheres com vida pública e social. A mãe-vinte-e-quatro-horas-assexuada e santificada é uma figura da modernidade, é uma figura do século XIX, que herdamos achando que sempre havia existido. Mas não havia. Então Foucault pergunta por que nós damos tanta ênfase à normatividade, à normatização e os gregos não? Como é a formação do jovem na Grécia antiga? O que se visava? Visava-se criar uma vida bela. E o que é uma vida bela? Uma vida bela é uma vida temperante, equilibrada. Temperante, para nós também, designa uma pessoa equilibrada. Agora, o que é equilibrado para nós e para eles? Para nós, equilibrado é uma pessoa que renuncia a si. Uma pessoa que diz não a tudo o que ela quer e não pode. Mas não pode segundo os parâmetros de quem? Para os gregos as pessoas não têm de renunciar a si. Elas têm de fazer um bom uso dos prazeres, usá-los na medida certa. Então, ser temperante para os antigos gregos, e o livro se chama " $O$ uso dos prazeres", mostra que os gregos entendem que formar um jovem é ensiná-lo a ser autônomo, dar condições para que ele possa decidir qual é a melhor medida das coisas para ele. Como é que ele pode se autotrabalhar, para não ser, por exemplo, um "galinha". Ele usa essa imagem do "galinha". Achei engraçado, porque é obvio, me senti vingada. Foucault diz que a virilidade não tem a ver com o "galinha". Este não é viril, ao contrário, na lógica dos antigos, é uma pessoa descontrolada, efeminada, não é temperante, porque é vítima das paixões, "não pode ver mulher". Para os gregos, o homem racional tem controle sobre o emocional, o instintivo, não é dominado pelos instintos e pelas emoções, como as mulheres. Ao contrário, o homem intemperante tende a ser uma pessoa autoritária, porque perde o controle sobre si e, logo, não pode ser um político. O político é o homem capaz de governar bem a cidade. Aquele que é capaz de ter uma vida bela, de ser tornar uma pessoa bela, de se trabalhar nesse sentido e ter uma vida exemplar, este sim pode ser o político, este é o cidadão.

A minha pergunta, então, é a seguinte: com essa herança, o que foi que nos aconteceu? Olhem para os nossos políticos: símbolos da intemperança, sinônimos de 
corrupção e decadência. O que foi que aconteceu? Como foi que nos perdemos? Ás vezes, vejo o esforço de buscar saídas em outros povos, por exemplo quando nos recomendam olhar para os índios. Mas Foucault, a meu ver, insiste em olhar para nós mesmos, e descobrir tesouros em nossa própria tradição. Não é preciso apenas olhar para os índios, para encontrarmos outros modos de viver e pensar. Olhemos também para nós mesmos, mas com um outro olhar. Procurando novas formas de vida e pensamento em nosso próprio passado, Foucault encontra os modos de subjetivação dos antigos gregos. Estes não investem nas formas da sujeição, mas nas da subjetivação. E o que é a subjetivação? É uma prática de constituição de si a partir de um trabalho em que você se modula, você se produz, porque ninguém nasce isso ou aquilo.

Em nosso mundo, tendemos a nos formar muito à direita, pela cultura capitalista do consumo, da ditadura do corpo, da normatização, da busca do lucro a qualquer custo em todas as coisas. As crianças se tornam desde cedo muito preconceituosas porque vêm de meios assim e é preciso todo esse trabalho de desconstrução e de produção de novas subjetividades, algo que não é isso que ouvimos por tantas décadas sobre a anulação de si. Como alguém pode ter um discurso em que exige que você se anule? Por que você não pode desejar o que você deseja? Por que o que você deseja é pecado? Ou porque o que você deseja é perversão, segundo a medicina e a moral burguesa? Quem criou o conceito de perversão sexual? Eu digo a vocês, foi o doutor Richard KrafftEbing, no século XIX. É um psiquiatra austríaco que fez muito sucesso. Assim como o doutor César Lombroso, que afirma que os índios têm um cérebro pequeno, as mulheres "não sei o quê", os anarquistas têm a orelha em asa, os bandidos têm o nariz adunco. É toda uma teoria da antropologia criminal que, no começo do século XIX, afirma o caráter da pessoa a partir da conformação biológica, é a famosa teoria da degenerescência.

Ora, é claro que se trata de um pensamento construído pelas elites europeias do século XIX, americanas também, reproduzido pelas elites brasileiras e latinoamericanas, mas que têm um custo político muito alto, porque se uma pessoa é incapaz de política ou de racionalidade porque a testa é "assim" ou "assada", porque o tipo de nariz é largo e a orelha é maior ou menor, acabou, não é? Tanto é que agora tem "lipoaspiração" e mil tipos de cirurgias plásticas de embelezamento, mas na época do Hitler, não havia. Isso justificava a eliminação dos deficientes, das crianças, porque 
essas pessoas não iriam servir para nada, segundo eles afirmavam. Aliás, os nazistas diziam que eliminá-las era um benefício que eles faziam, porque impediam a humanidade de sofrer e a própria criança deficiente de sofrer. Como um deficiente iria viver, se ele não conseguiria pensar? Esse era o raciocínio preliminar...

Nesse sentido, creio que o pós-estruturalismo, que entra na década de sessenta, ou um pouco antes, mas entra com a crise do marxismo, com o seu declínio, dá uma ênfase muito forte na noção de cultura, desnaturalizando. Porque o pós-estruturalismo afirma que nada é natural, que tudo é produto cultural. E aí o Foucault entra como também como um autor - por isso o identifico como um pós-estruturalista, assim como o Deleuze e o Derrida - porque ele afirma que tudo é construção cultural. Não adianta achar que alguém nasce pronto, ou que alguém nasce com determinadas características, ou "porque biologicamente..." Hoje essas discussões estão muito mais radicalizadas, sobretudo pelos "estudos feministas" e agora pela recente "teoria queer". A "teoria queer" (queer = estranho, bizarro) considera que o feminismo é limitado, porque se limita à mulher, enquanto que a teoria queer fala dos transexuais, da abolição das identidades sexuais e propõe que qualquer um pode ter qualquer sexo ou gênero. Por exemplo, nessa lógica, os índios podem praticar amor entre o mesmo sexo, mas não tem nada a ver com a homossexualidade e não significa que não podem relacionar-se com mulheres. Como os gregos que se casavam, mas achavam que a verdadeira relação de amor, a relação erótica verdadeira estabelecia-se entre homens iguais, o amor sendo algo possível apenas entre iguais. Entre dominante e dominado não poderia haver amor, porque há sujeição e poder.

Voltando a Thompson e Foucault, não há como negar que ambos escrevem muito bem, são literários, poéticos, o que foi um outro impacto para os historiadores, cansados do discurso objetivo, científico, neutro e duro. Ninguém conseguia mais ler sem se cansar, e de repente surgem essas duas figuras, mas também a Natalie Davis, a Michelle Perrot, o Alain Corbin, uma série de historiadores/as que escrevem literariamente, que trabalham a linguagem, então por aí se anuncia uma mudança muito grande. Thompson abriu o marxismo, deslocando essa idéia do cientificismo e da objetividade; a sua questão mais forte foi uma certa rebeldia em relação ao marxismo anterior, aquele que se centrava nas estruturas: por exemplo, discutia-se se o modo de produção no Brasil havia sido capitalista desde os inícios da colonização, como 
afirmava Caio Prado Junior, ou se era feudal, colonial-escravista, como dizia o PCB. Era uma discussão infindável. E a grande discussão de Thompson foi perguntar pelas classes e pelas pessoas que constituíam as classes. A classe operária não está pronta, não é um bloco estruturado desde sempre, alertou ele. Não falemos da classe operária como um quadro que está pronto. Não é isso, ele diz: a classe operária é composta por pessoas. Homens, mulheres, uns mais velhos, uns mais jovens, um era pescador que veio para a cidade, perdeu o emprego, o outro era um artesão, o outro era um professor que se proletarizou e essas pessoas se encontraram e não falavam a mesma língua; foi uma experiência de décadas em que elas foram trabalhar num espaço chamado fábrica e foram se formando enquanto classe. Então ele diz: a classe é um movimento, um processo, uma relação. Ele é muito radical ao afirmar que a classe operária se fez apesar dela, contra ela, porque na verdade nenhuma daquelas pessoas ficou feliz de perder o emprego de pescador, ou deixar de viver como artesão e perder tudo com a proletarização.

Sabemos o que é uma fábrica, sabemos o que é chegar num lugar, vindo de uma cidade pequena e viver o impacto da cidade grande, das profundas transformações que acarretam em nossas vidas. Thompson mostra que a classe operária não nasce do nada, que ela vem de tradições de luta do artesanato, de um outro universo, onde os trabalhadores eram autodidatas, tinham suas interpretações, suas referências, sua capacidade de pensar e que trazem isso para o novo mundo urbano-industrial. Sem dúvida, ele faz um trabalho maravilhoso, ao implodir velhas categorias do marxismo, renovando-o, potencializando-o com outros modos de pensar.

A meu ver, Thompson é fundamental para quem vai estudar a classe operária, mas mesmo o marxismo renovado tem os seus limites. O marxismo não criou determinadas categorias, por exemplo, o gênero. Isso não é um ataque. Se não queremos "Deus" na ciência, porque uma teoria tem de falar de tudo e dar conta de tudo? Que exigência é essa? O marxismo deu muito, aconteceu, produziu muitos e importantíssimos efeitos. É assustador pensar que podemos perder essa tradição, pois isso significa que ficaremos apenas com o positivismo, que é reacionário. Isso assusta porque o marxismo trouxe um grande impulso de transformação para nós todos, é um pensamento crítico, mas há limites na maneira de pensar determinadas questões. Por exemplo, para o feminismo, o marxismo é limitado. A categoria do gênero não nasce de 
dentro do marxismo, ela nasce fora, nasce da epistemologia feminista e aí o marxismo a incorpora. Tem a ver também com a própria transformação da sociedade brasileira onde, até 1970, havia duas ou três universidades no país e, de lá para cá, cresceram as universidades. É óbvio que quando crescem as universidades, cresce o número de autores, o número de estudos, as áreas, diversifica-se o pensamento. Não dá mais para ficarmos com apenas uma forma de pensamento, com um autor como o grande general, porque vira isso. Claro que nos lugares onde os estudos sobre cultura afro-descendente se fortalecem, emergem muitos autores que têm uma reflexão muito maior, muito mais interessante. $\mathrm{Na}$ área dos estudos feministas, isso se nota claramente. No caso dos estudos feministas, que crescem no Brasil da década de setenta para cá, sem dúvida nenhuma há uma apropriação do Marxismo, há uma apropriação do Foucault, do Derrida, mas, sobretudo, da discussão da crítica da identidade para as mulheres. Rosi Braidotti, crítica cultural feminista italiana, que trabalha em Amsterdã e é deleuziana, ela tem um livro chamado Sujeitos nômades, em que apresenta uma reflexão maravilhosa, da qual destaco sua proposta de pensar o feminismo de uma outra maneira. Para ela, o feminismo não é um movimento, uma teoria que vem para derrotar os homens, mas surge para "libertar as mulheres da mulher". Quem é a mulher, pergunta ela? A mulher é aquela figura que as mães queriam que fôssemos, ao menos em minha geração. Claro que o feminismo teve uma explosão enorme porque as mulheres invadiram o mundo público, começaram a falar e exigir que fossem ouvidas, pois as mulheres não falavam antes. Fiz um trabalho com história da prostituição, Os Prazeres da Noite, a que já me referi, em que analisei alguns romances do início dos anos 20. Achei uns romances escritos por mulheres sobre a prostituição, o que era raríssimo, porque mulher não falava de prostituição, assunto masculino, no passado. Se lembrarmos da teoria segundo a qual o cérebro feminino era mais mole, dá para entender essas demarcações. Lembremos que faz pouco tempo que as mulheres podem comprar apartamentos sem que um homem tenha de autorizar. Há uma série de coisas que as mulheres não podem fazer por conta dessa ideia de que a racionalidade masculina é mais forte, assim como a sexualidade. Há uma ideia de que o homem tem uma sexualidade diferente da mulher, tanto que existe um bairro, que é um espaço especial para os homens, chamado Zona do meretrício. Não é um espaço para as mulheres. É para as mulheres trabalharem, servirem, mas não é um espaço para elas. 
Mas na hora de apanhar, quem apanha? Com a nossa cabeça hoje, não dá mais para aceitar esse tipo de coisa. Se isso é a Modernidade, então adeus Modernidade.

Entendo que a história deve nos servir para criarmos outros modos de pensar, outros modos de enfrentar o diferente, para questionarmos o instituído. Não dá mais para acreditar em verdades únicas, ou para construirmos deuses capazes de darem explicações definitivas, como antes. Se somos desse mundo, todos nós somos limitados. Temos muitas potencialidades e precisamos uns dos outros para criar novas formas de ser, viver, pensar, amar. Mas para criar coisas novas, precisamos pensar coisas novas. Precisamos dar asas à imaginação, inventar e precisamos olhar para o passado e enxergar coisas que nunca tínhamos enxergado. Por exemplo, eu nunca tinha ouvido falar em "modos de subjetivação", ou em "artes da existência" no mundo Grecoromano, mesmo sendo historiadora.

Isso Foucault me apresentou, e considero-o um filósofo que constrói importantes e novas pontes na própria história, por exemplo, ao mostrar a importância da história antiga para quem não é um historiador da antiguidade clássica. Foi um impacto descobrir com Foucault que os gregos têm artes ou estéticas da existência, cuidado de si, epimeleia heautou. Este é um conceito e uma prática dos antigos gregos, que se refere a esse trabalho de construir a vida bela, o trabalho sobre si mesmo, o "cuidado de si”. Na alimentação, nos cuidados corporais, no cuidado com a vida sexual, com a leitura, com a escrita, com os pensamentos, entre outras coisas. Ora, poderíamos dizer assim: nosso mundo também fala em estética, mas não é disso que estamos falando. Não estamos falando do cuidar de si como algo que nos liga ao narcisismo, não é disso que estamos falando, porque disso estamos cansados e cansadas. Cansadas sobretudo. Os gregos têm outra noção de subjetividade, eles não acreditam num "eu" dessa maneira moderna. O cuidado de si que Sócrates recomenda foi traduzido na nossa tradição como "conhece-te a ti mesmo", mas os estudos históricos e filosóficos contemporâneos mostram que a frase é "cuida-te de ti mesmo" e o cuidado de si supõem também um conhecimento de si. Mas não tem a noção de que você está alojado dentro de você mesmo e que você se conhecerá acessando o que já está pronto lá dentro, como uma natureza, como essência. Eles acham que o cuidado de si envolve também uma relação com o outro, supõe um trabalho com o outro. Você se constitui, por exemplo, nas cartas. Assim, quando escrevo para alguém, trata-se de uma relação que estabeleço com o 
outro, mas nela eu falo de mim, conto meu cotidiano, o que me aconteceu de bom ou de ruim, enfim.... É uma escrita de si, mas é uma relação com o outro. E você só pode se constituir na relação com o outro, afinal, como se pode ser solidário, se não é numa relação com o outro? A visão que os antigos têm da constituição de si, da ética de si, da constituição do sujeito ético, da produção da subjetividade não passa por um isolamento do indivíduo, para fazê-lo meditar no pecado cometido, não se trata de confissão, ainda não estamos na era cristã. Aliás, confissão para quem? Quem é a autoridade que sabe a verdade? De onde vem essa noção? E Foucault abre uma grande discussão sobre a história do cristianismo, mostrando como a vitória ocidental do cristianismo mascarou e criou estereótipos sobre o que foi a cultura greco-romana, tanto que paganismo na nossa cabeça é tradução de bagunça. Que discursos o instituíram assim? O cristianismo que estava nascendo. Uma disputa de poder.

Foucault trouxe essa maneira de pensar a história, a história genealógica, que trabalha com outra noção de poder, um poder constitutivo das relações e das práticas discursivas, das palavras. Certamente Nietzsche é a grande referência, como ele aponta num artigo já muito famoso, "Nietzsche, a Genealogia e a História", publicado no livro Microfísica do Poder. Aqui se mostra que não é neutro chamar uma pessoa de homossexual, se homossexual é um conceito médico, do século XIX que quer dizer patológico e anormal. Então, não é sem efeitos nomear tal ou qual prática. Os gregos não têm essa palavra, o amor entre dois homens não é homossexualidade. $O$ que aconteceu, então, com a tradição?

Foucault e Thompson têm visões muito diferentes em alguns momentos sobre questões muito próximas, referentes à crítica da modernidade, à crítica do nosso mundo. Foucault dedica-se a fazer o que ele denomina de uma "ontologia histórica de nossa atualidade", um diagnóstico do presente. Ambos expressam certamente uma insatisfação enorme com a injustiça social, uma busca de ser diferente, de criar outras relações e com a capacidade de inventar outros mundos. Mas um vai pelo caminho da História e vai pela história dos dominados, dos que perderam, dos silenciados, dos vencidos. E o outro vai pelo caminho da Filosofia, também percebendo o que ficou de fora, o que não entra nem no campo de visibilidade, nem no de dizibilidade. O que não é visto, nem dito, por exemplo, as manifestações microscópicas do poder disciplinar. Assim, Foucault cria novos conceitos para pensar o presente e nesse sentido afirma: 
"não faço história do passado, faço história do presente". Ele trabalha com a noção de "história do presente", que já aparece em Vigiar e Punir, porque para ele o mundo que temos diz de um passado que não passa, porque a prisão está aí com todos os problemas que conhecemos, pior ainda que quando ela foi criada com o discurso de que era um progresso em relação ao suplício, para dizer que somos melhores que os que nos antecederam. Então ele afirma que quando fala dos gregos, está falando de nós também.

Dar visibilidade e nomear certas práticas é fundamental, porque se constrói uma linguagem que dá sentido e, portanto, pode fortalecer. $\mathrm{O}$ anarquismo, que foi vítima de tantas interpretações desqualificadoras, pode ser lido, com Foucault, em nova chave, com ênfase nas práticas de autogestão, de liberdade e não da desorganização e caos. No caso do feminismo, não foi à toa que trouxe a história das mulheres, porque com essa história toda nós percebemos quantos mitos haviam sido criados sobre nós mesmas, construindo uma identidade na qual não nos reconhecíamos, dizendo como éramos, como funcionávamos, o que deveríamos gostar ou detestar. Mas quem disse isso? Os discursos médicos do século XIX, masculinos e misóginos. Como podiam dizer para as mulheres como era o seu crânio, o que elas faziam? As mulheres não podiam abrir a boca. Há pouco tempo, houve um programa na televisão, o Saia justa, que perguntava: "por que não existem mulheres gênios?" Acho que a melhor resposta vem da escritora feminista inglesa Virginia Woolf, que escreve um livro chamado Um teto todo seu, em 1928, onde defende que a mulher não tem um "teto todo seu". Segundo ela, quando um homem escritor está em casa, todos se preocupam em fazer o silêncio que lhe dará as melhores condições de trabalho; quando uma mulher vai para o computador trabalhar, logo vem a empregada: "Dona, é para comprar carne ou peixe?", vem o encanador, o porteiro do prédio... Então, ela diz que as mulheres precisam ter "um teto todo seu". É por isso que as mulheres no passado tinham de escrever na cozinha, escreviam um pouco e escondiam em seguida, porque os pais regulavam quem escrevia. Virginia, então, imagina se Skakespeare tivesse tido uma irmã, o que aconteceria com ela? Bem, como irmã do Shakespeare, ela certamente teria um certo talento, então iria estudar. Ela chegaria à universidade, mas não poderia entrar, pois esta era aberta apenas aos homens; na biblioteca, não poderia ler os livros, apenas os reservados às mulheres. Mas ela não desiste e resolve fazer uma peça de teatro escondido, pois o pai não deixa, porque achava que se a filha estudasse ficaria doida. Ela então vai para a cidade mostrar a peça 
para um diretor do teatro. O que ele faz? Pensa: "Ela é bonitinha".... Conclusão: vamos dizer que ele seja delicado e eles até namorem e se casem. Ela se encheria de filhos e cuidaria da casa, mas ficaria tão triste que, no final, acabaria se suicidando...

Esse texto é de 1928, e Virginia faz essa discussão sobre a dificuldade do acesso feminino a um espaço próprio. Assim como o feminismo trata do espaço feminino, outros grupos estão falando de si. O movimento negro fala dos negros e negras, o movimento gay fala de si. Na verdade, os diferentes setores perceberam que são três os que mandam e podem: os brancos, os proprietários ricos, os donos da verdade, que instauram as regras, e dizem que você tem de se comportar segundo as normas que são dadas de cima e o resto é perversão e pecado. É esse o nosso mundo. É uma maneira caricata de trazê-lo, mas é uma construção cultural e se é uma construção cultural, começou em algum momento e pode ser desfeita em outro.

Por isso, finalizo dizendo que enxergo esse momento aqui, de vocês, da experiência dessa Universidade e desse espaço de estudos como um momento de rito de passagem, de amadurecimento. A sensação que tenho é que, para vocês, se encerra um ciclo e começa outro e um pouco da avaliação histórica de como foi esse passado, de como começou e onde é possível se nutrir.

Agradeço novamente o convite e a possibilidade de participar desse momento histórico.

RECEBIDO EM: 03 de novembro de 2011

APROVADO EM: 02 de dezembro de 2011 